\title{
O confucionismo nos nossos dias: transmissão sincera
}

\author{
Ana Cristina Rodrigues Alves
}

\section{Comentários à tradução}

Traduzir do chinês para o português é tarefa árdua, devido à já tão conhecida e falada distância entre as línguas. Porém ainda que fosse maior a relação linguística, qualquer tradução supõe um trabalho de interpretação e reelaboração, como bem viram vários teóricos da tradução de Schleirermacher, passando por Nida até Mona Baker e Lefevere.

A escolha da tradução aqui apresentada enquadra-se no espírito da escola culturalista. Por isso se escolheu uma autora, Chen Yun, e um tema que enfatiza as questões culturais. Logo, com o presente trabalho pretende-se dar mais um passo em direcção à cultura chinesa. Quer-se saber o que pensam os chineses actuais da sua própria cultura: como lêem o passado e se situam perante ele. O tema não podia ser mais sugestivo, já que é uma tentativa de recuperação da tradição, que remonta não só à primeira república, mas aos Clássicos constitutivos da mundividência chinesa, aquela que há milénios vem a formar o espírito dos chineses. Nota-se na autora uma preocupação evidente em recuperar a tradição.

Porém o tempo vai passando, até para os chineses, e a tradição não pode ser recuperada sem mediações, sendo uma das mais importantes, como nos é dito logo no início do artigo, a tradução do pensamento clássico em linguagem actual. Hoje, como ontem, e entenda-se por este passado os primórdios dos tempos republicanos, é necessário proceder à tradução do chinês clássico para o chinês moderno. E como é que isso se faz? Não basta recorrer a estruturas linguísiticas simplificadas, é ainda preciso introduzir a forma antitética utilizada nos Clássicos. O chinês clássico tem um modo único de expressar os pensamentos linguísticos, 
impossível de captar sem um estudo, ou melhor, uma iniciação linguísitica que permita o acesso a um mundo tão antigo.

E o que possui este mundo antigo de tão valioso e importante? Afinal, é o eterno pensamento confucionista, onde os mais velhos assumem um papel decisivo na condução dos mais novos.

Outro aspecto cultural verdadeiramente interessante é que nesses tempos o pensamento confucionista não poderia ser recuperado sem mediações, e não apenas linguísiticas. Para que fosse aceite era importante recorrer a ensinamentos científicos, práticos e naturalistas, que se vêem enraizar numa outra tradição ainda mais profunda e autóctne, a taoísta, fortemente naturalista. No entanto, mesmo essa comunhão com a natureza, de uma outra linha de sentir, precisa do apoio do pensamento científico moderno, daí a transmissão quase científica de uma série de atitudes a tomar em tempo de trovoada.

E no final com a chamada de atenção para a recuperação dos manuais antigos, parece-nos preocupar a autora sobretudo a salvaguarda do ensino tradicional, o dos Clássicos, como não podia deixar de ser.

Mudam-se os tempos, mas o apelo à tradição continua entre os chineses, especialmente os dos Sul, que tão bem sabem acarinhar e conservar os seus costumes.

Vejamos agora alguns aspectos práticos da tradução.

Foi impossível realizar uma tradução literal do artigo. Nem tal seria desejável, já que a ordem gramatical das frases difere do chinês para o português.

Por vezes não se procedeu apenas à tradução, mas antes a uma tradaptação, ou seja, a uma mistura entre a tradução e a adaptação, e tal sucedeu logo no título. Numa tradução pelo sentido o título seria: Transmissão da Via Sincera, mas porque se contou com a mentalidade ocidental, adaptou-se o título para Transmissão Sincera.

Porém, nem sempre se privilegiou a comunicação do sentido ao público-alvo, por vezes, e em temas culturais fundamentais, optou-se por uma tradução estrangeirante, sendo o caso mais flagrante, a expressão que poderia facilmente ser traduzida por "harmomia natural", mas que, por razões filosóficas, se manteve: "harmonia entre as forças celestiais e humanas", já que o peso da ideia de Céu na cultura tradicional chinesa é inultrapassável. As forças naturalistas são assim o produto da conjugação entre o Céu e a Terra, que engloba os seres humanos, bem como todos os outros seres naturais.

Para concluir, defende-se que, dentro da medida do possível, todas as traduções estrangeirantes sejam acompanhadas de notas de rodapé, uma vez que 
introduzem conceitos estranhos à maneira de ver o mundo da vasta audiência que fala português.

\section{Apresentação da autora}

Chen Yun (陳云), nascida em Hong Kong, é o pseudónimo da autora especialista em comentários de política e cultura. Com vários artigos publicados no Ming Bao, na publicação mensal de Ming Bao, no Diário Económico de Hong Kong, entre outros, conta ainda com diversas publicações na Internet, nomeadamente no Yahoo.

Licenciou-se na Universidade Chinesa de Hong Kong em estudos comparados das culturas chinesa e inglesa. Continuou os seus estudos em Hong Kong e em Zhuhai, dedicando-se à literatura ocidental. Em 1994 doutorou-se em Filosofia pelo Departamento de História de Goettingen, na Alemanha, especializando-se em política popular. Depois de regressar a Hong Kong, trabalhou no Instituto de Investigação Política e nos gabinetes de Desenvolvimento das Artes e de Administração Civil.

Em 2009 foi contratada como Professora Auxiliar do Departamento de Chinês da Universidade de Lingnan.

O artigo agora traduzido foi publicado no jornal Ming Bao (明報) dia 20 de Abril de 2012 e pertence a uma colectânea intitulada 《急救中文》(Pronto-socorro ao Chinês) de 2012, editada em Hong Kong.

\section{Chen Yun Pronto-socorro ao Chinês}

\section{Transmissão sincera}

Nos meus tempos de escola, recorria-se a Clássicos adaptados à lingua actual e à herança republicana. Por exemplo, no capítulo "A trovoada", lia-se: "Há nuvens altas e baixas, mas todas têm electricidade. Cruzam-se os raios, com o relâmpago e o trovão a deixar os seus rastos, formando um todo, sonoro e luminoso no céu. O raio prossegue veloz, o som torna-se cada vez mais longínquo. Por isso se costuma dizer que primeiro se vê o relâmpago e só depois se ouve o trovão... Logo, em tempo de trovoada não nos devemos encostar a paredes altas, usar roupa húmida ou abrigar-nos debaixo de árvores, para não sermos atingidos por um raio." A fim de se penetrar progressivamente nas frases antitéticas dos Clássicos, recorria-se a explicações baseadas em expressões de auto-defesa por 
todos conhecidas. O capítulo "Algodão", que hoje pertence à biologia ${ }^{1}$, é uma das relíquias legadas pelas dinastias Ming e Qing.

O meu capítulo preferido é "Manuais da Nova Cultura Republicana” (1912), a primeira lição do sexto volume, intitula-se: "A Vida Humana", sendo esta a lição:

"A nossa vida pode ser comparada à das quatro estações. $\mathrm{Na}$ Primavera sopra um vento criativo e as plantas florescem, igualmente a meninice é cheia de vivacidade. Com as chuvas do Verão, a vegetação torna-se luxuriante, e os adultos atingem a maturidade. Do Outono para o Inverno faz cada vez mais frio e as plantas murcham e caem, assim também as pessoas envelhecem e decaem. $\mathrm{Na}$ natureza as estações sucedem-se ciclicamente. Mas as pessoas envelhecendo, já não rejuvenescem. Costuma dizer-se: O Tempo não volta para trás ${ }^{2}$.

Aqui apresento uma lição dos meus últimos anos escolares. Hoje parece difícil compreender como podia ser um modelo para os jovens, no entanto lê-la era muito benéfico, porque os mais velhos ensinavam os mais novos. A lição assenta na "Harmonia entre as forças celestiais e humanas". Talvez a comparação entre os ritmos naturais de florescimento e declíneo das quatro estações e os humanos de nascimento, envelhecimento, doença e morte, pudessem substitutir melhor o pensamento confucionista. Há, no entanto, que ter em conta que o Céu permanece, mas as pessoas têm prazo. Por isso, os conselhos dos mais velhos são fundamentais para os mais novos valorizarem a juventude, aperfeiçoando-se constantemente, tal como os antigos pediam aos seus filhos. Eis o que pode ser considerado uma transmissão sincera!

PS.: Nos tempos de maior caos da república, pôde publicar-se este material de ensino em Hong Kong, que chegou até aos nossos dias. Sempre tive esperança que os manuais fossem reeditados, a fim de se preservar a cultura, a edição e a novidade dos conteúdos, de modo a transmiti-los aos vindouros. Mas ainda não tive nem tempo nem energia para o fazer. Fica a proposta de uma edição de "Leituras Escolhidas dos Clássicos". Os materiais estão feitos e engavetados há três anos.

1 A tradução literal seria flora, optou-se por biologia dado que é uma disciplina generalista, onde se enquadra a flora em muitos dos currículos ocidentais.

2 Conseguiu-se uma equivalência feliz de ditos entre o Chinês e o Português, situação nem sempre possível de alcançar em frases idiomáticas, sabida que é a singularidade das mesmas. 


\section{陳雲《急救中文》}

\section{真誠的傳道}

我童年的科學書, 用的都是浅白文言, 也是承繼民国遺風。例如〈 雷電〉一章, 說〈空中之雲, 或高或低, 各儲電氣。二電相觸, 乃發聲 光。其聲謂之雷, 其光之電, 實一物也。惟光行速, 聲行遲, 故常先見 電而後聞雷。……故雷雨之時, 勿倚高牆, 勿著洷衣, 勿立樹下, 皆避 電之法, 也。〉妙用古文的對仗與遞進的句法, 解釋物理與電雷自保的 常識。〈棉〉的一章, 是現代科學的植物誌, 行文却如明清的風物誌。

我最喜歡的一章, 是《共和國教科書新國文》（一九一二）第六 冊的第一課, 題爲〈人之一生〉, 課文如下:

〈人之一生, 猶一嵗之四時乎。春風和煦, 草木萌動, 一童子之活 法之活潑也。夏雨時行, 草木暢茂, 一壯年之發達也。秋冬漸寒, 草木 零落, 則有壯而老, 由老而衰矣。然冬盡春來, 循環不已, 人則老者不 可復壯, 壯者不可復少也。語曰: 〈時乎時乎不在來。〉

這是小學高年級的課文, 今日看來蔇深, 往日的兒童以小畢業為 準, 課文如老者向少年教誨, 讀之有益。課文寄託了〈天人合一〉, 人 之生老病死與四季的榮枯更替一體的儒家精神, 更有天地永久而人民有 期, 天人不能合一的悲嘆, 以老人的口吻, 勸論少年珍惜青春, 自強不 息, 如祖父啒咐孩子。這是真誠的傳道啊。

後記：民國兵慌馬亂之際, 仍可出此教本, 勝於香港今日。我常有 願望, 重新編訂此類教本, 保其文采、印刷, 將内容革新, 傳予香港下 一代, 可是時間與精力不足。即使構思了的《古文選讀》, 稿本都做好 了, 也擱置三年未能動筆。

《明報》二0一二年四月二十日

3 A tradução estrangeirante é muito importante do ponto de vista filosófico, porque esta harmonia estabelece-se entre o Céu e a Humanidade. Sendo, ao jeito do pensamento ocidental, uma harmonia natural. 